\title{
Edema Paru Akut pada Pasien Eklampsia: Perlukah Penanganan di Ruang Perawatan Intensif?
}

\author{
Roni Kartapraja ${ }^{1}$, Suwarman ${ }^{2}$ \\ ${ }^{1}$ Fellows Konsultan Terapi Intensif, ${ }^{2}$ Konsultan Terapi Intensif Departemen Anestesiologi dan Terapi Intensif \\ Fakultas Kedokteran Universitas Padjajadran-Rumah Sakit Hasan Sadikin Bandung
}

\begin{abstract}
Abstrak
Eklampsia adalah kelainan pada kehamilan yang ditandai dengan peningkatan tekanan darah disertai dengan proteinuria positif dan kejang yang muncul setelah minggu ke-20 kehamilan. Eklampsia dapat menimbulkan komplikasi terhadap ibu dan janin. Diantara komplikasi terhadap ibu yang muncul akibat eklampsia adalah edema paru akut. Edema paru akut terjadi pada $0,08 \%$ hingga $1,5 \%$ kehamilan dan merupakan salah satu penyebab kematian ibu hamil sehingga tergolong suatu keadaan darurat dan memerlukan penanganan segera. Faktor sirkulasi angiogenik, penurunan tekanan onkotik koloid, disfungsi sel endotel, atau peningkatan tekanan intravaskular disertai dengan peningkatan beban jantung diduga menjadi faktor penyebab terjadinya edema paru akut pada eklampsia. Penegakan diagnosa serta pemberian terapi yang tepat pada edema paru akut harus dilakukan sesegera mungkin untuk menurunkan angka mortalitas dan morbiditasnya. Terapi yang diberikan meliputi pemberian obat -obatan dan atau bantuan ventilasi mekanik. Penggunaan bantuan ventilasi mekanik dilakukan dengan pendekatan strategi lung recruitment yang bertujuan untuk memperbaiki oksigenasi paru dan mampu meningkatkan kemampuan penyapihan ventilator serta mencegah kerusakan paru iatrogenik. Disamping pemantauan hemodinamik secara berkesinambungan, penggunaan ventilasi mekanik merupakan indikasi bagi pasien eklampsia dengan edema paru akut untuk menjalani perawatan di ruang rawat intensif.
\end{abstract}

Kata kunci: eklampsia; edema paru akut; unit perawatan intensif; ventilasi mekanik

\section{Acute Pulmonary Edema in Patient with Eclampsia: are Really Need a Intensive Care Unit Treatment?}

\begin{abstract}
Eclampsia is a disorder in pregnancy which is characterized by an increase in blood pressure accompanied by positive proteinuria and seizures that appear after the 20th week of pregnancy. Eclampsia can cause complications for the mother and fetus. Among the complications of the mother that arise due to eclampsia are acute pulmonary edema. Acute pulmonary edema occurs in $0.08 \%$ to $1.5 \%$ of pregnancy and is one of the causes of death of pregnant women so it is classified as an emergency and requires immediate treatment. Angiogenic circulation factors, a decrease in colloid oncotic pressure, endothelial cell dysfunction, or an increase in intravascular pressure accompanied by an increase in cardiac load are thought to be factors causing the occurrence of acute pulmonary edema in eclampsia. The diagnosis and the provision of appropriate therapy in acute pulmonary edema must be done as soon as possible to reduce its mortality and morbidity. The therapy provided includes the administration of medicines and or mechanical ventilation assistance. The use of mechanical ventilation assistance is carried out with a lung recruitment strategy approach that aims to improve lung oxygenation and be able to improve ventilator weaning capabilities and prevent iatrogenic lung damage. In addition to continuous hemodynamic monitoring, the use of mechanical ventilation is an indication for eclampsia patients with acute pulmonary edema to undergo treatment in the intensive care unit.
\end{abstract}

Key words: eclampsia; acute pulmonary edema; intensive care unit; mechanical ventilation 


\section{Pendahuluan}

Edema paru akut (EPA) merupakan salah satu penyebab utama morbiditas/mortalitas ibu hamil dengan eklampsia yang ditandai oleh adanya keluhan sesak yang tiba-tiba dan seringkali disertai dengan agitasi. Satu penelitian tertutup yang dilakukan di Skotlandia yang meneliti risiko penyebab kematian ibu hamil menempatkan edema paru akut sebagai penyebab ke empat kematian ibu hamil dan karenanya memerlukan penanganan segera di ruang perawatan intensif. Angka kejadian edema paru akut pada kehamilan tergolong rendah, berkisar antara $0.08 \%$ hingga $1.5 \%$. Rendahnya angka ini kemungkinan karena kurangnya pelaporan kejadian sehingga tidak semua kejadian edema paru akut pada kehamilan tercatat secara statistik. ${ }^{1}$

\section{Patogenesis Edema Paru Akut}

Edema paru ditandai oleh akumulasi cairan di ruang interstitial paru dan alveoli yang mencegah difusi oksigen dan karbon dioksida yang memadai. Secara umum edema paru akut seringkali disebabkan oleh lebih dari satu faktor risiko. Edema paru akut dapat disebabkan oleh gangguan pada utama fungsi kardiovaskular dan aliran cairan ke interstitium paru. ${ }^{2}$ Tekanan hidrostatik, tekanan osmotik koloid dan permeabilitas kapiler sangat menentukan jumlah cairan dalam interstitium paru. Hal tersebut dijelaskan oleh persamaan Starling:

\section{Transcapillary fluid filtration rate $\alpha$}

$$
\mathrm{K}_{\mathrm{f}}\left[\left(\mathrm{P}_{\mathrm{mv}}-\mathrm{P}_{\mathrm{t}}\right)-\left(\mathrm{COP}_{\mathrm{mv}}-\mathrm{COP}_{\mathrm{t}}\right)\right]
$$

di mana: Kf adalah koefisien ultrafiltrasi, permeabilitas kapiler; Pmv adalah tekanan mikrovaskulatur, yang mendekati tekanan arteri-vena; $\mathrm{Pt}$ adalah tekanan hidrostatik jaringan; COPmv adalah tekanan osmotik koloid mikrovaskulatur; dan $\mathrm{COPt}$ adalah tekanan osmotik koloid jaringan. ${ }^{3}$

Tekanan hidrostatik ditentukan oleh fungsi jantung di mana komponen kuncinya adalah preload, denyut jantung, irama jantung, kontraktilitas, lusitropi, dan afterload. Tekanan hidrostatik juga ditentukan oleh tonus arteri dan vena melalui aktivitas sistem saraf dan sirkulasi zat vasoaktif. ${ }^{3}$ Hubungan antara eklamsia dan EPA sangat berkaitan erat. Beberapa penelitian menyatakan bahwa etiologi hipertensi pada eklampsia menjadi penyebab yang mempermudah terbentuknya EPA pada pasien eklampsia. Hipertensi akut yang memicu timbulnya EPA terjadi karena aktifasi system saraf simpatis yang kemudian menyebabkan peningkatan afterload dan redistribusi cairan dari sirkulasi peripheral ke pembuluh paru. Hal tersebut menyebabkan terjadinya akumulasi cairan dan penurunan oksigenasi paru. Selain karena mekanisme hipertensi tadi, tidak dilakukannya pembatasan terapi cairan pada wanita hamil dengan eklampsia juga turut meningkatkan resiko terjadinya EPA. ${ }^{3}$

Hal ini dipengaruhi pula oleh faktor-faktor yang meningkatkan tekanan hidrostatik, faktor-faktor yang menurunkan tekanan osmotik koloid, atau faktor-faktor yang meningkatkan permeabilitas kapiler, sehingga meningkatkan resiko pada wanita hamil mengalami edema paru akut. ${ }^{4}$ Selain itu, faktor kontribusi lain yang menyebabkan terjadinya EPA pada eklampsia adalah pelepasan vasopresin arginin yang dimediasi oleh baroreseptor, yang menyebabkan akumulasi cairan dan hiponatremia. Hal-hal tersebut diatas menjelaskan mengapawanita hamil dengan eklampsia berpotensi mengalami EPA sebab selain wanita hamil mengalami perubahan secara fisiologis pada sistem kardiovaskular dan respirasinya, kondisi eklampsia kemudian menjadi faktor yang menambah berat resiko tersebut. ${ }^{2,4}$

\section{Diagnosis Edema Paru Akut}

Ada sejumlah gejala klinis yang umumnya terkait edema paru akut yaitu sesak napas, ortopnoea, agitasi, batuk dan tanda-tanda lain seperti takikardia, takipnea, ronchi dan mengi serta penurunan saturasi oksigen. Pemeriksaan radiologi paru menunjukkan gambaran redistribusi pada lobus atas paru, garis Kerley-B, serta gambaran infiltrate pada paru. Penurunan nilai $\mathrm{PaO}_{2}$ pada analisa gas darah, EKG serta ekhokardiografi dapat membantu penegakan diagnosis edema paru akut. ${ }^{4}$ 


\section{Indikasi Rawat Ruang Intensif}

Hingga saat ini sebagian besar tata laksana edema paru akut dilakukan berdasarkan pengalaman klinis saja, dan belum berdasarkan suatu randomized control study. Beberapa negara telah mengeluarkan guideline sebagai panduan terapi EPA. Panduan-panduan tersebut memiliki beragam pendekatan dan metoda namun prinsip dasarnya adalah sama. ${ }^{1}$

Prinsip dasar penanganan edema paru akut yaitu menjaga oksigenasi dan ventilasi paru yang adequate serta menurunkan beban jantung dengan cara menurunkan preload ventrikel jantung kiri, menurunkan afterload ventrikel jantung kiri, dan mencegah terjadinya iskemia jantung. Tujuan utamanya adalah mengurangi gejala, menjaga tekanan darah yang adekuat, menjaga oksigenasi dan perfusi organ, serta mengurangi akumulasi cairan ekstraselular. ${ }^{1}$ Edema paru akut pada kehamilan merupakan kasus emergensidan perlupenanganan sesegeramungkin sebab hal terburuk yang mungkin terjadi akibat edema paru akut adalah terjadinya henti jantung. Karena itu tata laksana paling tepat terhadap kondisi tersebut adalah dilakukan di ruangan yang mampu memberikan monitoring hemodinamik secara berkesinambungan dilengkapi dengan ketersediaan ventilasi mekanik maka tempat perawatan yang ideal pada pasien ini adalah di ruang rawat intensif. ${ }^{1}$

\section{Tata Laksana Edema Paru Akut}

Tata laksana EPA meliputi pemberian obat-obatan yang diantaranya: nitrat, diuretik dan inotrop. Selain itu, sebagian besar pasien memerlukan topangan ventilasi mekanik. ${ }^{5}$

\section{Nitrat}

Mekanisme kerja nitrat adalah relaksasi otot polos, menyebabkan venodilatasi dan pengurangan preload akibatnya pada dosis rendah. Dosis yang lebih tinggi menyebabkan dilatasi arteriolar, sehingga mengurangi afterload dan tekanan darah. Khususnya di arteri koroner, dilatasi ini menghasilkan peningkatan aliran darah koroner. Tindakan ini secara kolektif meningkatkan oksigenasi dan mengurangi beban kerja jantung. ${ }^{4}$
Secara umum, nitrat dapat diberikan secara sublingual. Rumah sakit dapat menggunakan infus karena pemberian intravena lebih disukai karena kecepatan onset dan kemampuan untuk titrasi dosis. Nitrat dikaitkan dengan hipotensi dan oleh karena itu pemantauan tekanan darah sangat penting untuk memastikan tekanan darah sistolik dipertahankan di atas $90 \mathrm{mmHg}$. Mereka tidak boleh diberikan jika tekanan darah sistolik kurang dari $90 \mathrm{mmHg}$ atau pasien memiliki stenosis aorta yang parah, karena pasien ini tergantung preload. Jika pasien baru-baru ini menggunakan inhibitor fosfodiesterase, seperti sildenafil, nitrat dikontraindikasikan. ${ }^{5}$ Nitrat umumnya ditoleransi dengan baik dengan efek samping yang paling umum adalah sakit kepala. ${ }^{5}$ Efek samping lainnya termasuk refleks takikardia dan bradikardia paradoks. Nitrat juga dikaitkan dengan takifilaksis, dengan toleransi berkembang dalam 16-24 jam pemberian terus menerus. ${ }^{4}$

\section{Furosemid}

Diuretik diindikasikan untuk pasien dengan bukti kelebihan cairan. Loop diuretik seperti furosemide mengurangi preload dan harus ditahan atau digunakan secara bijaksana pada pasien yang mungkin mengalami penurunan volume intravaskular. ${ }^{4}$ Pemberian intravena lebih disukai, dengan dosis furosemide berkisar $40-80 \mathrm{mg}$. Dosis yang lebih tinggi dalam kisaran digunakan untuk pasien yang sudah menggunakan diuretik oral atau dengan penyakit ginjal kronis. Bolus awal dapat diberikan secara intravena perlahan dan diulangi 20 menit kemudian jika diperlukan. Setelah bolus, infus intravena terus menerus dapat dipertimbangkan, dimulai pada kecepatan 5-10 mg per jam. ${ }^{5}$ Pemberian dosis yang lebih tinggi dikaitkan dengan peningkatan dispnea yang lebih besar serta dengan memburuknya fungsi ginjal dan peningkatan rawat inap ke perawatan intensif. Pemasangan kateter diperlukan untuk memonitor produksi urin. ${ }^{5}$

\section{Inotrop}

Obat inotropik intravena diindikasikan dalam edema paru akut ketika ada hipotensi dan bukti penurunan perfusi organ. Penggunaannya terbatas pada situasi klinis ini pada pasien yang sakit kritis karena mereka dikaitkan dengan 
lama tinggal di rumah sakit yang lebih lama dan peningkatan mortalitas. ${ }^{4}$ Dalam kasus gangguan fungsi ventrikel kiri dan hipotensi, terapi lini pertama adalah infus dobutamin intravena. Serta tindakan inotropik positifnya, dobutamin memiliki efek vasodilatasi perifer yang dapat mengakibatkan memburuknya hipotensi, yang mungkin memerlukan penatalaksanaan dengan vasopressor. ${ }^{4,5}$ Dobutamine dapat menyebabkan aritmia dan dikontraindikasikan jika pasien mengalami aritmia ventrikel atau fibrilasi atrium yang cepat. Inotrop lain yang dapat meningkatkan curah jantung dan meningkatkan perfusi perifer adalah milrinon. Ini seharusnya hanya digunakan untuk manajemen jangka pendek gagal jantung berat yang belum menanggapi perawatan lain. Milrinone dapat meningkatkan mortalitas pada eksaserbasi akut gagal jantung kronis. ${ }^{5}$

\section{Ventilasi Mekanik}

Sindrom gangguan pernapasan akut (Acute Respiratory Distress Syndrome (ARDS) adalah sindrom hipoksemik yang memerlukan penanganan utama menggunakan ventilasi mekanik. ${ }^{6}$ Meskipun ventilasi mekanis menyelamatkan jiwa, namun dapat menyebabkan cedera paru yang diinduksi ventilator (VILI). Oleh karena itu, tujuan ventilasi mekanik adalah untuk mencapai pertukaran gas yang memadai sambil meminimalkan cedera paru-paru. ${ }^{6,7}$

Pada tahun 1970, dikembangkan suatu rumus matematika untuk memperkirakan tekanan intrapulmoner dalam paru yang diberi ventilasi heterogen. ${ }^{8}$ Dinyatakan bahwa pada antarmuka paru-paru yang terbuka dan kolaps dengan tekanan transpulmonary sebesar $30 \mathrm{~cm} \mathrm{H}_{2} \mathrm{O}$ dapat menghasilkan tekanan lokal $140 \mathrm{~cm} \mathrm{H}_{2} \mathrm{O}$. Berdasarkan perkiraan ini, muncullah hipotesis bahwa tegangan geser mungkin menjadi penyebab utama kerusakan struktural dan VILI. ${ }^{9}$ Untuk meminimalkan stres geser dan atelektrauma pada paru-paru dengan ventilasi heterogen diberlakukan strategi lung recruitment. ${ }^{7,8}$

Berbagai penelitian menunjukkan bahwa ventilasi mekanis dengan strategi lung recruitment dapat diberikan pada pasien dengan ARDS dan terbukti lebih baik dalam memperbaiki fungsi paru serta meningkatkan kemampuan penyapihan dari ventilator. ${ }^{8,9}$ Oleh karena itu, strategi perlindungan paru harus diterapkan pada pasien dengan ARDS yang menggunakan ventilator mekanik. Dibandingkan dengan ventilasi konvensional, strategi perlindungan dikaitkan dengan peningkatan kelangsungan hidup dalam 28 hari, tingkat penyapihan yang lebih tinggi dari ventilasi mekanik, dan tingkat barotrauma yang lebih rendah pada pasien dengan sindrom gangguan pernapasan akut. ${ }^{10,11}$

Ventilasi mekanik dengan plateau pressure lebih rendah dari $35 \mathrm{~cm} \mathrm{H}_{2} \mathrm{O}$ dan positive end-expiratory pressure (PEEP) telah direkomendasikan dan tampaknya nilai PEEP awal yang tinggi menunjukkan hasil yang bermanfaat bahkan ketika nilai tekanan dataran tinggi meningkat, selama tekanan penggerak tidak berubah secara tidak proporsional. ${ }^{11,12}$ Sebagian besar pasien yang diobati dengan lung protection strategy mungkin gagal mencapai perlindungan optimal terhadap barotrauma dengan strategi eksperimental ini. Teori ini didukung oleh bukti tomografi terkomputasi baru-baru ini yang menunjukkan bahwa respons terhadap PEEP dalam populasi pasien ARDS yang heterogen sangat bervariasi dan sering menyebabkan distensi berlebih dibandingkan dengan lung recruitment. ${ }^{10}$

Studi menunjukkan bahwa pada pasien yang menderita ARDS yang diberikan terapi lung protection strategy memiliki tiga faktor prognostik penting. Rata-rata PEEP yang digunakan selama 36 jam pertama, dan tekanan mengemudi (tekanan dataran tinggi-PEEP) selama 36 jam pertama adalah indikator prognostik terkuat. ${ }^{11}$ Semua variabel pernapasan lainnya memiliki kepentingan sekunder. Nilai PEEP yang lebih tinggi dan driving pressure yang lebih rendah secara independen terkait dengan kelangsungan hidup yang lebih baik. ${ }^{11,12}$

\section{Simpulan}

Edema paru akut pada kehamilan dengan eklampsia merupakan indikator morbiditas yang signifikan dan dapat menyebabkan kematian sehingga merupakan suatu kondisi darurat dan 
perlu penanganan segera. Penegakan diagnosa edema paru akut dengan cepat dan dilanjutkan penanganan berupa pemberian obat-obat serta bantuan ventilasi mekanik diharapkan akan memperbaiki prognosa. Dikarenakan tata laksana edema paru akut pada kehamilan dengan eklampsia sangat komprehensif dan memerlukan monitoring hemodinamik yang berkesinambungan, hal tersebut menjadikan suatu indikasi bagi edema paru akut pada eclampsia untuk dirawat di ruang rawat intensif.

\section{Daftar Pustaka}

1. Dennis A.T, Solnordal C.B. Acute pulmonary oedema in pregnant women. Peri-operative medicine, critical care, and pain 2012; 67(6).

2. Chestnut DH. Obstetric Anesthesia Principles and Practice, 3rd edn. Philedelphia, Mosby, USA: Elsevier, 2004.

3. Chu M, Dierking E. Intensive Care Unit Issues in Eclampsia and HELLP Syndrome. Int J Crit Illn Inj Sci. 2017 Jul-Sep; 7(3): 136-141.

4. Dennis AT, Solnordal CB. Acute Pulmonary Oedema in Pregnant. Anaesthesia The Association of Anaesthetists of Great Britain and Ireland. 2012.

5. Cantwell R, Clutton-Brock T, Cooper G, Dawson A, Drife J, Garrod D, Harper A, dkk. Saving mothers' lives: reviewing maternal deaths to make motherhood safer: 2006-2008. The eighth report of the confidential enquiries into maternal deaths in the United
Kingdom. British Journal of Obstetrics and Gynaecology 2011; 118 ( Suppl 1): 1-203.

6. Dennis AT. Transthoracic echocardiography in obstetric anaesthesia and obstetric critical illness. International Journal Obstetric Anesthesia 2011; 20: 160-8.

7. Baird A. Acute Pulmonary Oedema: in general practice. Australian Family Physician Vol. 39, No. 12, december 2010.

8. Pordeus A, Katz L, Soares M, Maia S, Amorim M, Wane D. Acute pulmonary edema in an obstetric intensive care unit: a case series study. Medicine. 2018; 97:28.

9. Granado R, Mehta R. Fluid overload in the ICU: evaluation and management. BMC Nephrology. 2016; 17:109.

10. Calvalcenti AB. Effect of Titrated vs Low Positive End-Expiratory Pressure (PEEP) on Mortality in ARDS. JAMA. 2017; 318:14.

11. Jabbari A, Alijanpour E, Maleh P.A, Heidari B. Lung protection strategy as an effective treatment in acute respiratory distress syndrome. Caspian J. Intern Med. 2013 Winter; 4(1): 560-63.

12. Pollock W, Rose LN, Dennis CL. Pregnant and postpartum admissions to the intensive care unit: a systematic review. Intensive Care Medicine 2010; 36: 1465-74. 